\title{
INVESTIGATION OF MOUNTAIN GLACIER STORAGE AND ITS CHANGES DURING 2000-2016 IN THE WESTERN TIBETAN PLATEAU USING COMBINED GROUND AND SATELLITE OBSERVATIONS
}

\author{
Yinsheng Zhang ${ }^{1,2, *}$ Xiaojuan Zou ${ }^{1}$, Haifeng Gao ${ }^{1}$ \\ ${ }^{1}$ Key Laboratory of Tibetan Environment Changes and Land Surface Processes, \\ Institute of Tibetan Plateau Research, Chinese Academy of Sciences. - (yszhang, xjzou, gaohaifeng)@itpcas.ac.cn \\ ${ }^{2}$ CAS Center for Excellence in Tibetan Plateau Earth Sciences, Beijing, China \\ Commission VI, WG VI/4
}

KEY WORDS: Upper Indus River Basin (UIB), Glacier Thickness, Ground-Penetrating Radar, GlabTOP2, Glacier Volume, Glacier Elevation Change

\begin{abstract}
:
The Upper Indus River Basin (UIB) has developed the largest midlatitude mountain glaciers worldwide. Ice thickness and volume distribution are important prerequisites for glaciological and hydrological investigations. In this paper, we presented detailed estimates of ice thickness in UIB region. Using ground penetrating radar, we measured glacier ice thickness on six typical glaciers; we obtained the parameters of the GlabTOP2 from these measurements and analyzed its uncertainty. Using the verified GlabTOP2 model, we simulated glacier ice thickness and volume in UIB subcatchments. The simulated results indicated that the UIB glacier thickness distribution was not uniform, ranging from 0 to $488 \mathrm{~m}$, with an average thickness of $78 \mathrm{~m}$. Total volume was defined as $1269.70 \mathrm{~km}^{3}$ in 2000, which corresponded to $1142.73 \mathrm{~km}^{3}$ water volume. According to the calculated discharge data from the Besham hydrological station, the total glacier volume of UIB generally can supply water resources for the downstream area for at least 15 years. And the glacier surface elevations generally decreased from 2000 to 2016 in UIB subbasins, although there was significant spatial heterogeneity in the seven subcatchments. The annual glacier surface elevation change rate of the Hindu Kush area was the smallest, followed by that of the Karakoram. The greatest glacier elevation change rate was observed in the Western Himalaya, indicating rapid glacial melting.
\end{abstract}

\section{INTRODUCTION}

\subsection{General Instructions}

The high mountains of Asia are home to the largest concentration of glaciers outside the polar regions. The rivers in this so-called "Water Tower of Asia" are all fed from the Tibetan Plateau (TP) (Brun et al., 2017; Farinotti, 2017). The Indus River lies at the Hindu Kush-Karakoram-Himalaya (HKH) confluence, located in the northwest TP, with elevations ranging from 300 to $8800 \mathrm{~m}$ a.s.l. The Upper Indus Basin (UIB) lies upstream of the Indus River in Pakistan. Under the combined influence of Western disturbances, the Indian summer monsoon, and the Tibetan anticyclone climatic features, the UIB comprises the world's highest, most heavily glaciated watersheds (Bishop et al., 2010; Farhan et al., 2015; Yao et al., 2012). More than 70\% of the freshwater supply upstream of the Tarbela Dam is primarily dependent on seasonal snow and glacial melting (Bamber, 2012; Minora et al., 2015). Colloquially referred to as the "Pakistan Water Tower," the UIB provides domestic and hydroelectric power, as well as water for activities such as agricultural irrigation, to 80 million people downstream (Immerzeel et al., 2010; Lutz et al., 2014; Pritchard, 2017). Concurrent with global warming, comprehensive knowledge of glacier volume and its change is becoming a fundamental prerequisite for assessing the cryospheric contribution to sea-level rise (Radić et al., 2011), future glacier response to climate change (Cogley, 2012; Vaughan et al., 2013), and glacier resource management. This knowledge can assist in the development of protective measures against extreme water shortages on seasonal and longer timescales. Glacier thickness is an indispensable boundary condition. Numerous investigators have applied a wealth of approaches to estimate ice thickness (Bahr et al., 2015; Chen et al., 1990; Cogley, 2012; Liu et al., 2002). Based on the $V-A$ scaling, slope-dep, GlabTop2, and HF models, the ice volume of the Karakoram and Himalayas has been estimated to be in the range of $2187-3531 \mathrm{~km}^{3}$ (Frey et al., 2014), values that were calibrated with only the Baltoro and Chhota Shigri glaciers (Singh et al., 2012). Thus, model estimations still have large uncertainties. The application of measured data can help to improve the accuracy of model results at the regional scale (Martín et al., 2016). extreme water shortages on seasonal and longer timescales. Glacier thickness is an indispensable boundary condition.

In light of the special geographical and strategic position of the UIB, the ancient Silk Road from China to South Asia and the modern Karakoram Highway linking China and Pakistan both pass through its terminal. Detailed mapping and further groundbased investigations were carried out in 1974/1975 as well as in the past few years by different scientific expedition teams (Zhang et al., 1996). Glacier volume estimation has been extremely significant for social development, although it is still difficult to conduct on a large number of glaciers. The main objectives of this paper are to (1) present new measured data for glacier thickness obtained in 2016-2018 using the GPR technique; (2) compare the measured and simulated ice thickness and select optimal parameterization scheme; and (3) discuss the glacier surface elevation change in separated subcatchments and possible explanations.

* Corrseponding author: yszhang@itpcas.ac.cn 


\section{METHODOLOGY}

\subsection{Study region}

The UIB has an extensive upstream area of approximately $1.72 \times$ $10^{5} \mathrm{~km}^{2}$ at the Tarbela dam, an estimate derived from the SRTM 90m DEM (Dahri et al., 2016; Immerzeel et al., 2010; Khan et al., 2015), and is comprised of 8 principal drainage units. The Gilgit and UIB_D watersheds that drain the Hindu Kush range, and the Hunza, Shigar, and Shyok watersheds that drain the Karakoram range both have a large proportion of surface elevation above $3500 \mathrm{~m}$ and are heavily glaciated. In addition, the Astore, Kharmong, and Shiquanhe subcatchments drain the Western Himalaya range. Overall, nearly $12 \%$ of the UIB is covered by glaciers. According to the latest Pakistan Glacier Inventory, the total surface area of the 11,413 glaciers in this region is $1.86 \times$ $10^{4} \mathrm{~km}^{2}$, with $70 \%$ of these glaciers distributed in high altitude sub-basins such as the Hunza, Shigar, and Shyok.
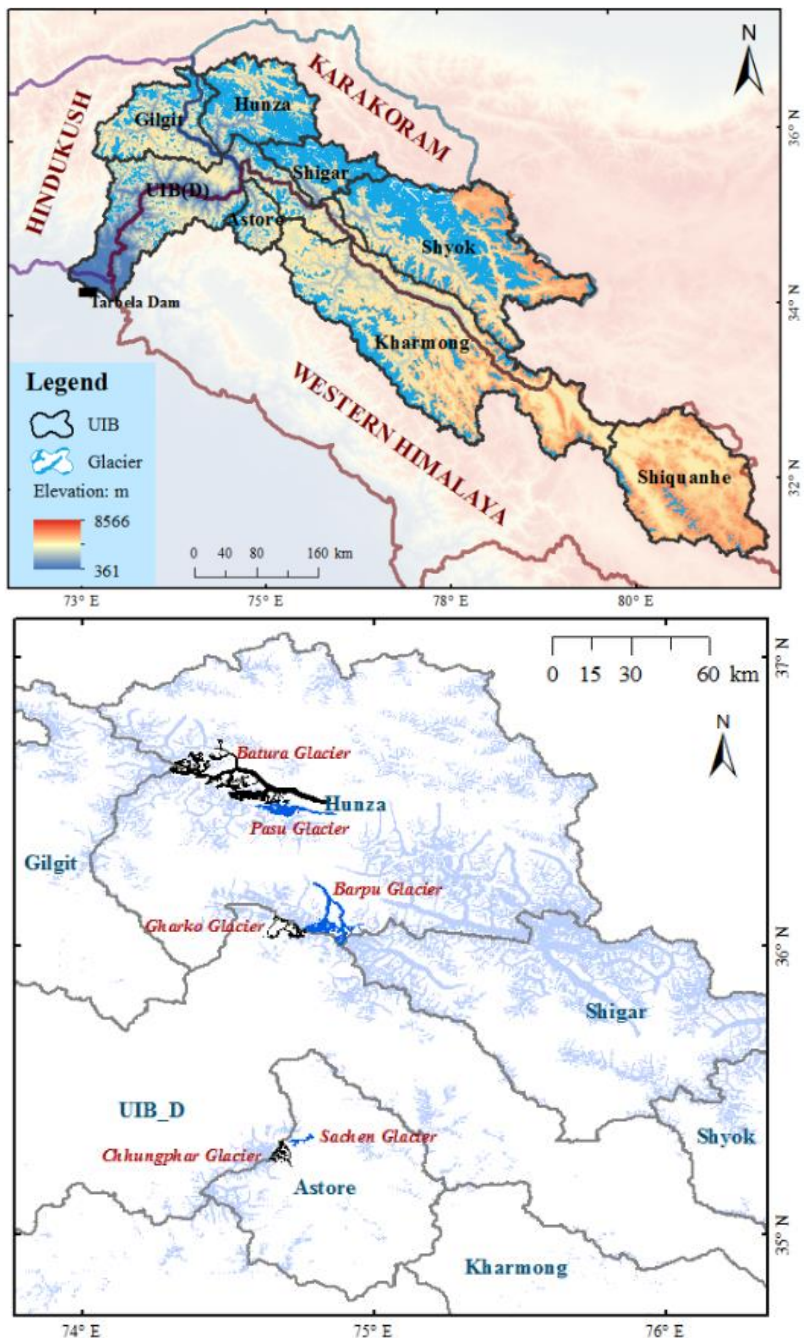

Figure 1. The study region and subregions and sources of the glacier inventory, in the northwestern TP. The distribution of glaciers in the UIB area in the HKH ranges and the location of the six observed glaciers in the UIB region, where the SRTM-X DEM voids are filled with erroneous interpolations.

\subsection{GPR Field Working}

In this study, we used an enhanced B-1 homemade radar (Cold and Arid Regions Environmental and Engineering Research
Institute, Chinese Academy of Sciences, CAREERI-CAS) with a separate transmitter and receiver and a common offset geometry with a point-measuring mode and a $5-\mathrm{MHz}$ resistively loaded dipole antenna length of $10 \mathrm{~m}$. it's a gravimetric method that uses electromagnetic waves to acquire glacier thickness, has been widely and successfully applied on the TP, although measurement fieldwork has rarely been carried out in western South Asia due to limited accessibility (Gergan et al., 1999; Ma et al., 2010; Singh et al., 2012)Because of the undulated microtopography, we carried a transmitter and receiver, separated by a fixed distance of $5 \mathrm{~m}$, on the glacier surface along the transverse profile and used the devices to record the measurements with a distance ranging from 50 to $200 \mathrm{~m}$. On the two-dimensional radar image, we derived the glacier thickness $(h)$ from the vertical axis radar wave and calculated the two-way travel time by the following equation:

$$
h=\frac{\sqrt{v^{2} t^{2}-x^{2}}}{2}
$$

Where $t=$ the radar wave two-way travel time

$x=$ the distance of the antennas

$v=$ the velocity of radar signal in the glacier.

We determined the accuracy of the glacier thickness estimations from the GPR measurements according to two factors: the accuracy of the measurement system and the properties of the ice and bedrock. We used the time interval between the direct wave arrival through the air and the reflections from the glacier bed to calculate ice thickness at the center site between the transmitter and receiver. In this study, we assumed the speed of electromagnetic wave propagation in the ice and air to be 0.169 and $0.200 \mathrm{~m} \mathrm{~ns}^{-1}$, respectively. The relative error was within the accuracy requirements of glaciology research. We determined the ice thickness at measured points of different survey profiles for two glaciers by identifying the ice-rock interface in the radar images and performed the calculation by multiplying radar-wave travel time with the velocity of the radar signal in the glacier. We selected six typical glaciers in the UIB region for GPR measurement implementation, including the Batura, Pasu, Sachen, Chhungphar, Barpu, and Gharko glaciers. These glaciers vary in size and shape and are likely spatially representative of the region. The Batura has been classified as a Mustagh glacier given its multi-branched structure that is nourished largely by avalanches (Hewitt, 2011). It flows from a maximum altitude of $\sim 7769 \mathrm{~m}$ a.s.l. down to the Hunza River, at $2529 \mathrm{~m}$ a.s.l.. The Pasu, with an area of $62.2 \mathrm{~km}^{2}$, has retreated approximately 1.5 $\mathrm{km}$ since the end of the $19^{\text {th }}$ century, and is characterized by small terminal moraine consisting essentially of till in the form of hummocks and low parallel ridges (Owen et al., 1989). The Sachen and Chhungphar glaciers are both in the Nanga Parbat, an area featuring extremely steep terrain and sharp vertical gradients. The Sachen, ranging from 3373 to $5085 \mathrm{~m}$ a.s.l., is nourished largely by ice-fall avalanches (Shroder et al., 2000). The Chhungphar is located in the southern foothills of Nanga Parbat and has an area of $24.9 \mathrm{~km}^{2}$. The Barpu has a length of $24.5 \mathrm{~km}$ and an area of $90.57 \mathrm{~km}^{2}$, and the Gharko is the primary branch of the Burche, covering an area of $16.5 \mathrm{~km}^{2}$ and extending 13.9 $\mathrm{km}$ in length. Table 1 provides detailed information for these six glaciers.

\subsection{GlabTop2 ice thickness model}

The GlabTop2 is a grid-based and slope-dependent estimation model. Glacier thickness was calculated for the automated selection of randomly picked DEM cells within the glacierized areas, requiring glacier outline, mask, and DEM as input data (Frey et al., 2014). Linsbauer et al. (2009) established and 
developed the GlabTop2 based on the flow mechanics of an infinitely wide glacier according to the empirical relationship between the average basal shear $(\tau)$ at the glacier bed and differences in glacier action (Nye, 1952; Paterson, 1970). This relationship suggests that ice thickness can be calculated from the ice surface characteristics using the following formula:

$$
\begin{gathered}
h=\frac{\tau}{f \rho g \sin (\alpha)} \\
\Delta H \leq 1.6 \mathrm{~km}, \tau=0.005+1.598 \Delta H-0.435 \Delta H^{2} \\
\Delta H>1.6 \mathrm{~km}, \tau=150 \mathrm{kPa}
\end{gathered}
$$

Where $\quad h=$ glacier thickness

$\tau=$ the average basal shear stress

$f=$ shape factor

$\rho=$ ice density $\left(900 \mathrm{~kg} / \mathrm{m}^{3}\right)$

$g=$ gravitational acceleration $\left(9.81 \mathrm{~m} / \mathrm{s}^{2}\right)$

$\alpha=$ mean surface slope

$\Delta H=$ vertical glacier elevation range

And $f$ is depends on the cross-section aspect ratio, representing half the width divided by the thickness of the midpoint, and is usually set to 0.8 for all glaciers (Paterson, 1994);
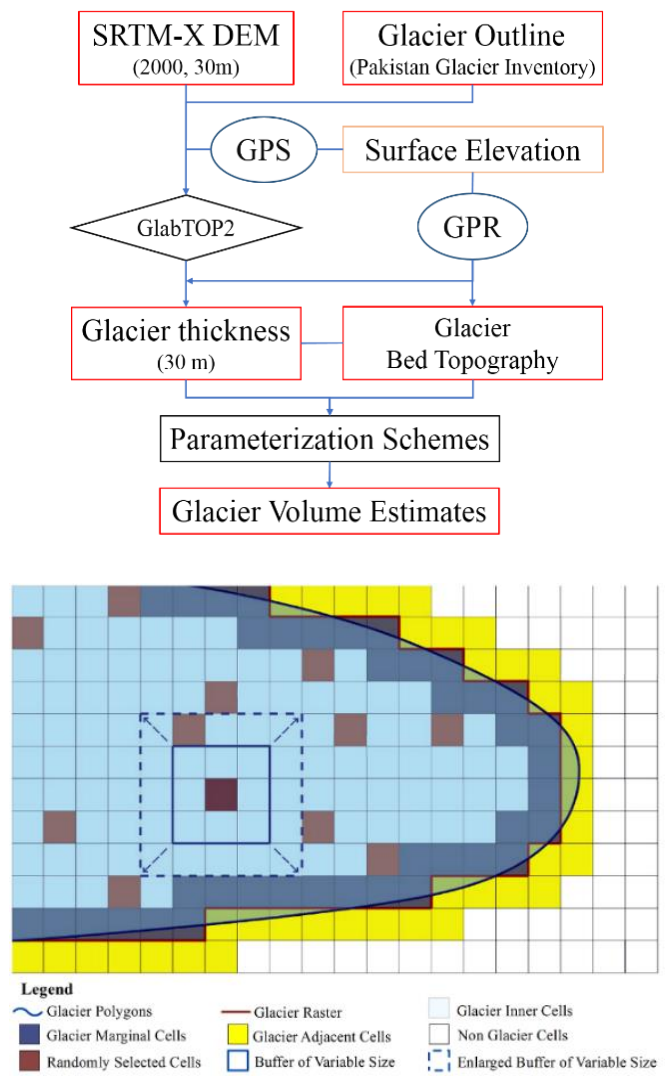

Figure 2. Data set and work flowchart for processing and schematic illustration of GlabTOP2 (Frey et al., 2014).

These parameters can be calculated for each glacier individually, which thus can be used for comparison; GlabTOP2 requires estimating only the parameters $\tau$ and $f$. The specific work flowchart for processing and schematic illustration of GlabTOP2 is shown in Figure 2.

\subsection{Glacier inventory and GPS survey}

Glacier outlines and areas were sourced from the most recent Pakistan Glacier Inventory (PGI) released by SUPARCO and ITPCAS. In addition, the second Chinese Glacier Inventory (CGI) and the GLIMS Randolph Glacier Inventory 6.0 (RGI 6.0) were used as the database for determining the glacier outlines of the portions of the Shyok and Kharmong subcatchments not covered by the PGI. The glacier surface elevations in the year 2000 were extracted from the SRTM-X DEM, which is available free of charge at a 30-m resolution from the USGS, and the 2017 surface elevation was surveyed using a portable Global Positioning System device (Shtech GPS) to determine the location of the GPR survey. The combination of GIS, GPS, and GPR data was checked with an accuracy of $0.1-0.3 \mathrm{~m}$ and processed using the UTM zone 43N/WGS 84 projection.

\subsection{Digital Elevation Model}

The quality of modeled ice thickness simulation depends on the digital elevation model (DEM) resolution. We derived the topographic parameters for GlabTOP2 calculation used in this study from the Shuttle Radar Topography Mission Digital Elevation Model (SRTM-X DEM), which has a global high spatial resolution of 1 arc-second (approximately $30 \mathrm{~m}$ ). SRTM$\mathrm{X}$ DEM data were released in February 2011 by NASA and NGA and were acquired using a radar interferometry technique. The model has been used successfully to collect radar data over $80 \%$ of the earth's land surface between $60^{\circ} \mathrm{N}$ and $56^{\circ} \mathrm{S}$ latitude interval. The free SRTM-X DEM is available from the U.S. Geological Survey (USGS) website: http://dds.cr.usgs.gov/ srtm/version2_1/SRTM1. In subsequent studies, we created a mosaic of the DEM model and projected it to the Universal Transverse Mercator Projection system (UTM43N) and World Geodetic System 1984 ellipsoidal elevation (WGS84).

\section{RESULTS}

\subsection{Ice thickness measurements}

The GPR survey fieldwork took place from August to October in 2016-2018. Three transverse profiles were measured in the tongue area of the Batura glacier; seven profiles were measured in the Sachen, including four transverse and three longitudinal, covering most of the glaciers. The transverse profiles were measured from the terminus to the upper reaches of the ablation zone, while the longitudinal profiles were taken along the central flow line. Five profiles were obtained on the Gharko, including three transverse and two longitudinal, two transverse profiles and two longitudinal profiles were performed on the Pasu. The GPR fieldwork on the Chhungphar was carried out along a central longitudinal profile and two transverse profiles within a small range below $3000 \mathrm{~m}$ a.s.l. In total, we completed $27 \mathrm{GPR}$ profiles, comprising 187 data points.

\begin{tabular}{|c|c|c|c|}
\hline Glacier & $\begin{array}{c}\text { Area } \\
\left(\mathrm{km}^{2}\right)\end{array}$ & $\begin{array}{c}\text { Elevation Range } \\
(\mathrm{m})\end{array}$ & $\begin{array}{c}\text { GPR } \\
\text { Profiles/Points }\end{array}$ \\
\hline Batura & 243.5 & $2508-7771$ & $3 / 24$ \\
Pasu & 62.2 & $2575-7569$ & $3 / 10$ \\
Barpu & 90.6 & $2813-7304$ & $6 / 63$ \\
Sachen & 9.5 & $3359-5026$ & $7 / 44$ \\
Chungphar & 24.9 & $2870-4734$ & $3 / 16$ \\
Gharko & 30.3 & $3084-6801$ & $5 / 30$ \\
\hline
\end{tabular}

Table 1. Detail information of six observed glaciers in UIB region 


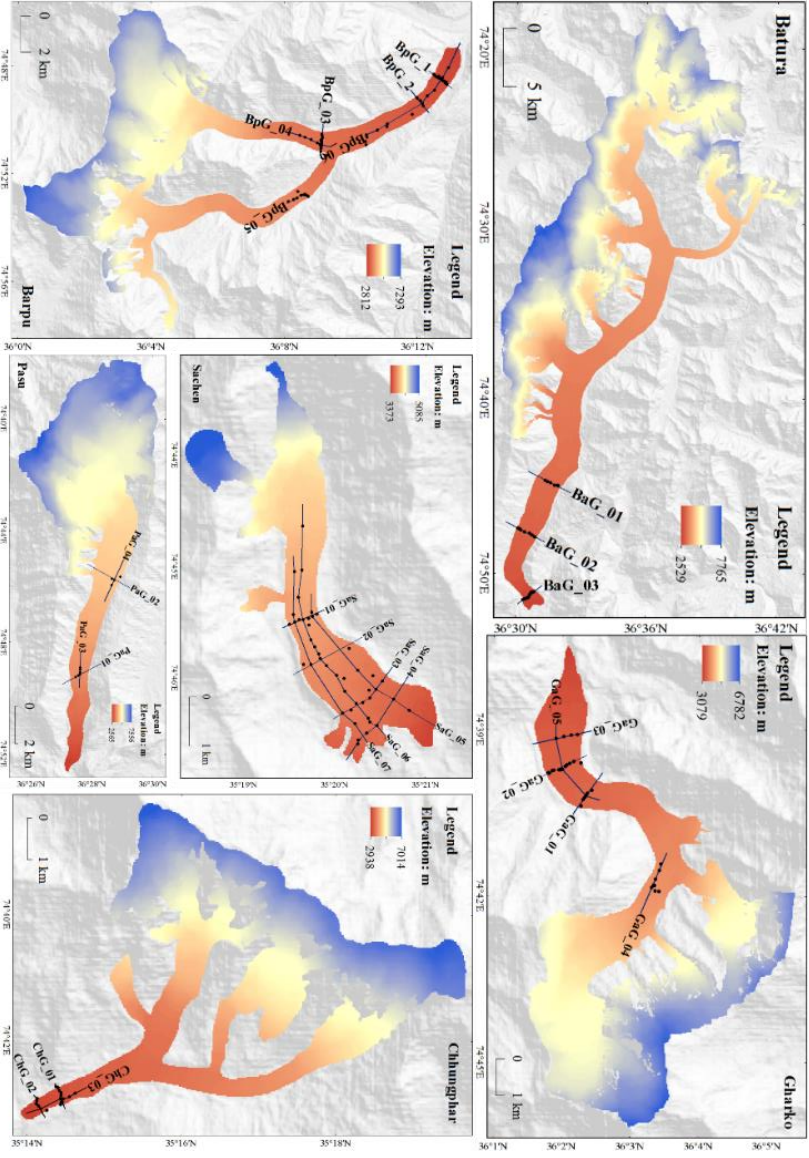

Figure 3. Hillshade views of SRTM-X DEM with the location of topography of six typical glaciers and the survey routes by GPR and GPS measurements made in the past two years. Black dots indicate measured points, and black lines denote the measured profiles.

\subsection{GlabTop2 parameter calibration}

The GlabTop2 estimation results were directly compared to the GPR values using nine different optimizing parameterization schemes. Model estimation was based on the SRTM-X DEM from 2000, although the GPR measurements were obtained in 2017. Therefore, the calculated and measured results cannot be compared directly since the glacier surfaces have changed over the past few decades. However, the measured glacier bed positions can be compared indirectly for model validation, since glacier erosion occurs over a large timescale (Koppes et al., 2009) and glacier beds can therefore be assumed as relatively stable. The GlabTop2 was run with parameter $\tau_{\max }=100-150 \mathrm{kPa}$, gradually increased in increments of $20 \mathrm{kPa}$ and $50 \mathrm{kPa}$, and $f=$ $0.7-0.9$, gradually increased in increments of 0.1 . The nine schemes displayed a large amount of consistency. As $\tau$ decreased and $f$ increased, the GlabTop2 began underestimating the actual glacier thickness. Conversely, as $\tau$ increased and $f$ decreased, the GlabTop2 began overestimating the actual values. The NSE values were $>90 \%$, indicating that the GlabTop 2 performed well. The MD ranged between $\pm 50 \mathrm{~m}$, and the RMSE varied from $55.23-80.60 \mathrm{~m}$. Among the 9 schemes, 3 exhibited relatively good results: (1) $\tau=150 \mathrm{kPa}$ and $f=0.9$; (2) $\tau=120 \mathrm{kPa}$ and $f=$ 0.7 ; (3) $\tau=120 \mathrm{kPa}$ and $f=0.8$. The first scheme had the lowest RMSE and highest NSE; the second had the lowest MD. For more accurate simulations, we compared the glacier bed profiles of these 3 schemes.
We discovered that when $\tau=120 \mathrm{kPa}$ and $f=0.7 / 0.8$, the measured orography of the estimated glacier bed was quite close to that of the actual bed. When $\tau=150 \mathrm{kPa}$ and $f=0.9$, however, the simulated glacier bed shape was much shallower than the bottom of the measured glacier bed, producing a relatively large error compared to that of the other two schemes. In addition, when $\tau=120 \mathrm{kPa}$ and $f=0.7 / 0.8$, the glacier beds varied only slightly; thus, either of the two schemes was suitable for glacier bed estimation of the entire UIB region. In the end, we selected the parameterization scheme with $\tau=120 \mathrm{kPa}$ and $f=0.8$, since the vast majority of the glaciers in the UIB basin are slender and narrow. Hence, the smaller $f$ value matches the actual orography.
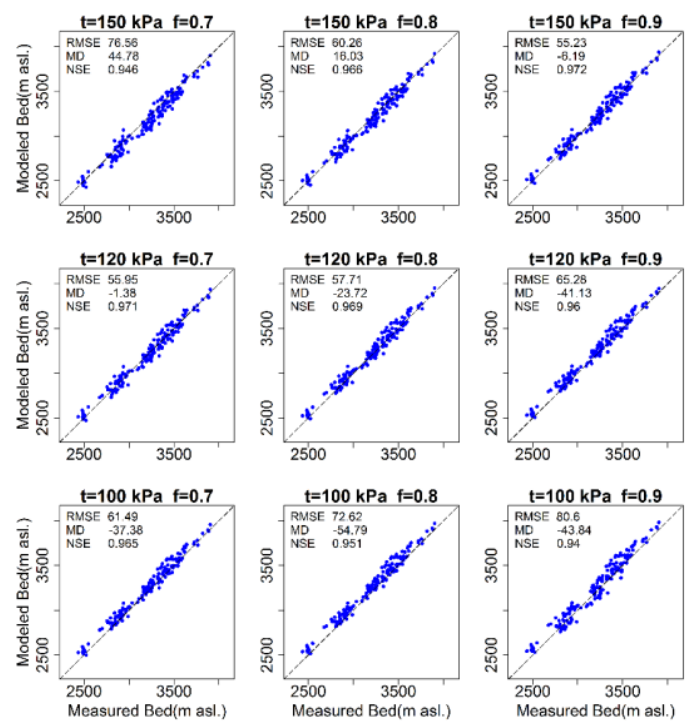

Figure 4. Comparison between measured (x-axis) ice thickness results from GPR and estimated (y-axis) results from GlabTOP2 with nine different parameterization schemes. Numbers on top-

left indicate the RMSE, root mean square error; MD, mean deviation; and NSE, Nash Sutcliffe efficiency.

\subsection{Simulation of UIB ice thickness and volume}

\begin{tabular}{|c|c|c|c|}
\hline Subbasins & Shiquanhe & Kharmong & Astore \\
\hline Glacier Number & 598 & 2741 & 378 \\
Glacier Area $\left(\mathrm{km}^{2}\right)$ & 183.35 & 2569.67 & 304.52 \\
Ice thickness_Mean (m) & 48.54 & 59.72 & 48.64 \\
Ice thickness_Max (m) & 260.96 & 344.97 & 253.40 \\
Standard Deviation (m) & 51.16 & 53.39 & 46.10 \\
Glacier Volume $\left(\mathrm{km}^{3}\right)$ & 7.65 & 120.89 & 14.80 \\
\hline
\end{tabular}

\begin{tabular}{|c|c|c|c|c|c|}
\hline Hunza & Shigar & Shyok & Gilgit & UIB_D & UIB \\
\hline 1288 & 391 & 3877 & 978 & 1284 & 11,535 \\
3054.16 & 2628.21 & 7574.58 & 1022.18 & 929.66 & $18,266.33$ \\
73.44 & 87.41 & 82.41 & 49.29 & 39.92 & 78.33 \\
335.88 & 479.09 & 488.12 & 279.00 & 245.48 & 488.12 \\
61.25 & 78.33 & 79.10 & 42.02 & 36.04 & 55.92 \\
224.06 & 229.36 & 585.63 & 50.32 & 37.00 & 1269.70 \\
\hline
\end{tabular}

Table 2. Detailed glacier information of UIB subcatchments

The calculated ice thickness distribution values in the UIB region were significantly higher in the Karakoram range (335.88$488.12 \mathrm{~m}$ ) than in either the Hindu Kush (245.48-279.00 m) or the Himalaya (260.96-344.97 m). The largest glacier volumes 
were found in the Hunza, Shigar, and Shyok subcatchments (224.06 $\mathrm{km}^{3}, 229.36 \mathrm{~km}^{3}$, and $585.63 \mathrm{~km}^{3}$, respectively), comprising approximately $83.67 \%$ of the total volume. Because the glaciers in the Karakoram range are the most concentrated, it is almost a semi-dispersive glacier area. Smaller glacier volumes were observed in the Kharmong, Gilgit, and UIB_D subcatchments (120.89 $\mathrm{km}^{3}, 50.32 \mathrm{~km}^{3}$, and $37.00 \mathrm{~km}^{3}$, respectively), and the smallest volumes existed in the Shiquanhe and Astore subcatchments $\left(7.65 \mathrm{~km}^{3}\right.$ and $14.80 \mathrm{~km}^{3}$, respectively). The glacier water resource distributions in the UIB area are not uniform. The total glacier volume was $1269.70 \mathrm{~km}^{3}$ in 2000 , which converts to $1142.73 \mathrm{~km}^{3}$ of melted water, 15.17 times the total discharge at the Besham hydrological station located at the outlet of the UIB, which meets the water demands of the Indus River downstream areas.

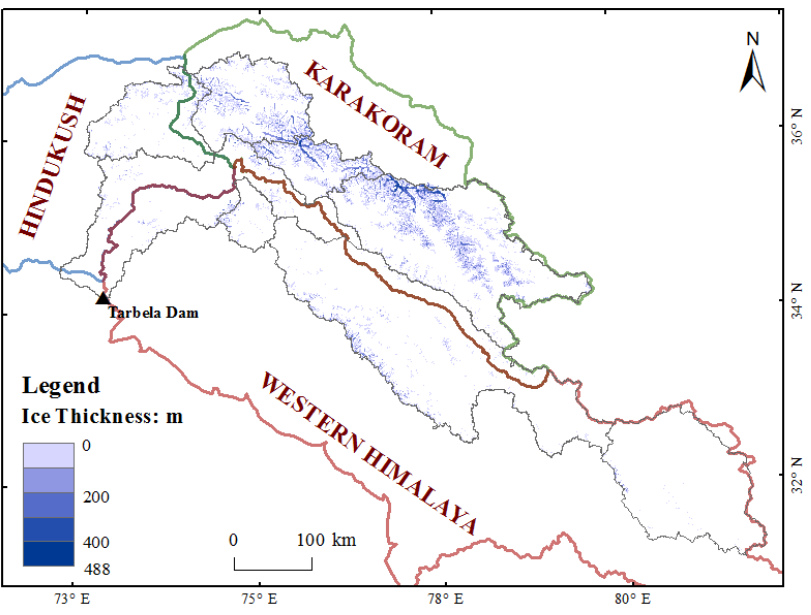

Figure 5. Spatial heterogeneity distribution of ice thickness of the entire UIB.

\subsubsection{Glacier surface elevation changes...}

Glacier surface elevation change data in the HKH ranges can be downloaded from Brun's published Aster paper (https://doi.org/10.1594/PANGAEA.876545). We processed the ice surface elevation change results in the UIB area for the period 2000-2016. After eliminating the outliers, we obtained the 95\% confidence interval subset of the original data. It was discovered that the glacier elevation changes all decreased, in general, from 2000 to 2016, although there was significant spatial heterogeneity in the glacier elevation changes among the seven subcatchments. Specifically, the glacier surface elevation change rates in the Gilgit and UIB_D subcatchments were very small in the Hindu Kush area, with values of $<-0.02 \mathrm{~m} \mathrm{yr}^{-1}$. In the Karakoram area, the glacier surface elevation change rates of the Hunza, Shigar, and Shyok subcatchments were relatively smallall $<-0.1 \mathrm{~m} \mathrm{yr}^{-1}$. In contrast, the highest glacier elevation change rates-nearly $-0.3 \mathrm{~m} \mathrm{yr}^{-1}$ - were reported in the Astore and Kharmong sub-basins in the Western Himalaya range, indicating that the glaciers in this area are rapidly melting.

Disregarding glacier area change, each sub-basin has experienced a trend of decreasing ice reserves. Among them, the Shyok and Kharmong subcatchments have lost the largest amount of glacial reserves. This has to do with the fact that the Shyok sub-basin covers a large area and contains a huge number of glaciers. Meanwhile, in winter, the influence of the prevailing westerly circulation on the Kharmong sub-basin is far less than on other sub-basins. In contrast, the Gilgit and UIB_D subcatchments have lost the least amount glacial reserves, most likely because these two sub-basins are under the influence of the large-scale westerly circulation, which provides sufficient winter precipitation for glacier mass accumulation.

\section{CONCLUSIONS}

In this paper, we used GPR, GPS, glacier inventory, and DEM data to study the glacier thickness and related volume spatial distribution of the UIB region. Some conclusions are as follows. On the basis of the latest GPR measured glacier depth of six typical glaciers in the UIB subcatchments, we verified the GlabTOP2 model and optimized the most suitable parameterization scheme. We found that when the value of $\tau$ was smaller and $f$ was larger, GlabTOP2 underestimated the actual measured ice thickness. In contrast, when the value of $\tau$ was larger and $f$ was smaller, GlabTOP 2 overestimated the actual measured ice thickness. Three favorable schemes had suitable RMSE, NSE, and MD values: in one scheme, $\tau$ equaled $150 \mathrm{kPa}$ and $f$ equaled 0.9 ; in the other two schemes, $\tau$ equaled $120 \mathrm{kPa}$ and $f$ equaled 0.7 or 0.8 . By comparing the ice bed morphology with these three selected schemes, we found that when $\tau$ equaled $120 \mathrm{kPa}$ and $f$ equaled 0.8 , the measured GPR glacier bed orographic was much closer to the GlabTOP2 estimated results. Considering the vast majority of long and narrow glaciers in the entire UIB region, when $f$ equaled 0.8 , the assessment was more realistic.

We estimated the glacier volume of the UIB region by combing direct GPR ice thickness observations with GlabTOP2 model approaches. The extensive GPR measurements in the UIB were geographically well distributed, covering three typical watersheds. On the basis of the PGI and SRTM-X DEM input data, the GlabTOP2 model results indicated that the ice thickness distribution of the UIB ranged from 0 to $488 \mathrm{~m}$, with an average thickness of $39.92-87.41 \mathrm{~m}$. The total ice reserve was 1269.70 $\mathrm{km}^{3}$ in 2000, and homogeneous ice mass distribution was significantly higher in Karakoram than in Hindukush and Western Himalaya. The number, area, and ice storage on the northward, northeastward, northwestward, and westward slopes were significantly greater than the southward aspects, mainly because of limited solar radiation on the northward slope. Moreover, the humid air mass comes from the WDs, combined with the uplift effect of the steep terrain. With global warming and rapid shrinkage of glaciers in the TP in recent decades, accurate glacier volume estimates in this region will receive unprecedented attention for scientific research. The integration of GPR, GPS, and GIS data will make the field of glaciology more dynamic, comprehensive, exploratory, and predictive.

From the specific small watersheds, the Hunza, Shigar, and Shyok occupied an absolute proportion $(81.83 \%)$ of total glacier volume. Mean ice thickness was significantly higher in Karakoram than in the Hindukush and Himalaya ranges. This estimate was lower than the majority of previous assessments in the HKH region that applied an empirical formula and other physical models. These data provide the foundation for regional glacial change and water resource research. In addition to total glacier volume, knowledge about ice thickness distribution is important for several other fields of glaciology, including hydrology, regional climate modeling, and assessment of glacier hazards. The results of this study highlight the uncertainties related to estimates of freshwater reserves stored in the UIB region and their potential contribution to sea-level rise.

The total ice volume was $1269.70 \mathrm{~km}^{3}$, which corresponded to the $1142.73 \mathrm{~km}^{3}$ of glacier meltwater supplied for river discharge, which represents a significant high-quality freshwater resource in the lower reaches of the Indus. The total water volume was 15.17 times higher than the average annual discharge of the entire UIB region at the Besham Hydrological Station. Its distribution in the 
UIB is not uniform in the major tributaries. Although the consumption times of the eight subcatchments are significantly different, in general, the total glacial resource of the UIB area can supply water resources for the downstream area for at least 15 years to meet the water demands in the downstream areas of the Indus. The UIB is likely to face the water shortage difficulties in the future.

The glacier surface elevation changes all decreased generally from 2000 to 2016, but significant spatial heterogeneity exists in seven subcatchments. The annual glacier surface elevation change rate of the Hindukush area was the lowest and the second lowest was the Karakoram. In contrast, the highest glacier elevation change rate occurred in the Western Himalaya, showing rapid glacier melting.

\section{ACKNOWLEDGEMENTS}

This research was jointly funded by the National Key Research and Development Project (2017YFA0603101), the National Natural Science Foundation of China (41661144025, 4180011362); Strategic Priority Research Program (A) of CAS (XDA20060202); the CAS International Cooperation Project (131C11KYSB20160061); and the Youth Science Fund Project We appreciate Dr. Holger Frey and Dr. Horst Machguth for providing the GlabTOP2 model. Data for producing the figure are available from the corresponding author.

\section{REFERENCES}

Bahr, D., Pfeffer, W., Kaser, G., 2015. A review of volume-area scaling of glaciers. Reviews of Geophysics, 53(1), 95-140.

Bamber, J., 2012. Climata change: Shrinking glaciers under scrutiny. Natura, 483, 482-483.

Bishop, M., Bush, A., Copland, L. et al., 2010. Climate change and mountain topographic evolution in the central karakoram, pakistan. Annals of the Association of American Geographers, 100(4), 772-793.

Brun, F., Berthier, E., Wagnon, P. et al., 2017. A spatially resolved estimate of high mountain asia glacier mass balances, 2000-2016. Nature Geoscience, 10(9), 668-673.

Chen, J., Ohmura, A., 1990. Estimation of alpine glacier water resources and their change since the 1870s. Hydrology in Mountainous Regions, 193, 127-135.

Cogley, G., 2012. Glaciology: No ice lost in the karakoram. Nature Geoscience, 5(5), 305.

Dahri, Z. H., Ludwig, F., Moors, E. et al., 2016. An appraisal of precipitation distribution in the high-altitude catchments of the indus basin. Sci Total Environ, 548-549, 289-306.

Farhan, S., Zhang, Y., Ma, Y. et al., 2015. Hydrological regimes under the conjunction of westerly and monsoon climates: A case investigation in the astore basin, northwestern himalaya. Climate Dynamics, 44(11-12), 3015-3032.

Farinotti, D., 2017. Cryospheric science: Asia's glacier changes. Nature Geoscience, 10, 1-2.

Frey, H., Machguth, H., Huss, M. et al., 2014. Estimating the volume of glaciers in the himalayan-karakoram region using different methods. The Cryosphere, 8(6), 2313-2333.

Gergan, J., Dobhal, D., Kaushik, R., 1999. Ground penetrating radar ice thickness measurements of dokriani bamak glacier, garhwal himalaya. Current Science, 77(1), 169-173.

Hewitt, K., 2011. Glacier change, concentration, and elevation effects in the karakoram himalaya, upper indus basin. Mountain Research and Development, 31(3), 188-200.

Immerzeel, W., Van, B., Bierkens, M., 2010. Climate change will affect the asian water towers. Science, 328, 1382-1385.

Khan, A., Naz, B., Bowling, L., 2015. Separating snow, clean and debris covered ice in the upper indus basin, hindukushkarakoram-himalayas, using landsat images between 1998 and 2002. Journal of Hydrology, 521, 46-64.

Liu, S., Shen, Y., Sun, W. et al., 2002. Glacier variation since the maximum of the little ice age in the western qilian mountains, northwest china. Journal of Glaciology and Geocryology, 24(3), 227-233.

Lutz, A., Immerzeel, W., Shrestha, A. et al., 2014. Consistent increase in high asia's runoff due to increasing glacier melt and precipitation. Nature Climate Change, 4(7), 587-592.

Ma, L., Tian, L., Pu, J. et al., 2010. Recent area and ice volume change of kangwure glacier in the middle of himalayas. Chinese Science Bulletin, 55(20), 2088-2096.

Martín, E., Mangion, Z., Peter, J. et al., 2016. Spatial and temporal antarctic ice sheet mass trends, glacio - isostatic adjustment, and surface processes from a joint inversion of satellite altimeter, gravity, and gps data. Journal of Geophysical Research Earth Surface, 121(2), 182-200.

Minora, U., Senese, A., Bocchiola, D. et al., 2015. A simple model to evaluate ice melt over the ablation area of glaciers in the central karakoram national park, pakistan. Annals of Glaciology, 56(70), 202-216.

Nye, J., 1952. A comparison between the theoretical and the measured long profile of the unteraar glacier. Journal of Glaciology, 2(12), 103-107.

Owen, A., Derbyshire, E., 1989. The karakoram glacial depositional system. Zeitschrift für Geomorphologie, 76(Suppl.), 33-73.

Paterson, W., 1970. The sliding velocity of athabasca glacier, canada. Journal of Glaciology, 9(55), 55-63.

Pritchard, H., 2017. Asia's glaciers are a regionally important buffer against drought. Nature, 545, 169-174.

Radić, V., Hock, R., 2011. Regionally differentiated contribution of mountain glaciers and ice caps to future sea-level rise. Nature Geoscience, 4(2), 91-94.

Shroder, F., Bishop, P., Copland, L. et al., 2000. Debris - covered glaciers and rock glaciers in the nanga parbat himalaya, pakistan. Geografiska Annaler: Series A, Physical Geography, 82(1), 1731 .

Singh, P. Rathore, M., Bahuguna, I. et al., 2012. Estimation of glacier ice thickness using ground penetrating radar in the himalayan region. Research Communication, 103(1), 68-73.

Vaughan, D., Comiso, J., Allison, I. et al., Climate change 2013: The physical science basis observations of the cryosphere 2013. 
Yao, T., Thompson, L., Yang, W. et al., 2012. Different glacier status with atmospheric circulations in tibetan plateau and surroundings. Nature Climate Change, 2(9), 663-667.

Zhang, X., Chen, J., Wang, W., 1996. Recent Variations of the Batura Glacier in the Karakorum Mountains. Journal of Glaciology and Geocryology, 18, 33-45.

Revised April 2019 